\title{
Production, Purification and Characterization of Endopolygalacturonase by Bacillus subtillus
}

Nayab Munir*, Javaid Asad M and Haidri SH

Department of Biochemistry and Biotechnology, PMAS Arid Agriculture University Rawalpindi, Pakistan

\begin{abstract}
Plant cell wall is made up of complex carbohydrates like cellulose, hemicelluloses and pectin. Pectin is complex carbohydrates made up of galacturonic acid units linked by glycosidic linkage. For breakdown of this pectin microorganism require many different enzymes. Polygalacturonase is a pectinolytic enzyme catalyzed hydrolysis of a 1-4 glycosidic linkage in polygalacturonic acid by the addition of water. Polygalacturonase has two types; endopolygalacturonase and exopolygalacturonase. Endopolygalacturonase catalysis internal a 1-4 glycosidic linkage and exopolygalacturonase catalyze external a 1-4 glycosidic linkage in Pectate molecules. Endopolygalacturonase has various applications especially fruit juice industries used for clarification of juice as well as in food industry for maceration of vegetables. Endo-PG produced by fungus works in acidic $\mathrm{pH}$ and at low temperature but the application of endo-PG in food industry and in cloth industry needs an enzyme that works at high temperature and also in alkaline conditions. Bacillus subtillus was used as reference strain. By using different substrates like apple peels, radish peels and citrus peels, it was concluded that citrus peels produce maximum enzyme concentration. Further characterization showed that EPG produced by Bacillus subtillus have optimum temperature of $60^{\circ} \mathrm{C}$ and optimum $\mathrm{PH} 5$. Maximum fold of purification was observing with Gel filtration. Molecular weight of enzyme was $67 \mathrm{kd} . \mathrm{V}_{\max }$ for EPG produced by Bacillus subtillus was $1.21 \mathrm{mg} / \mathrm{ml}$ and $\mathrm{Km}$ was $2423 \mathrm{~mol} / \mathrm{min} / \mathrm{mg}$.
\end{abstract}

Keywords: Bacillus subtillus; Galacturonic acid; Endopolygalacturonase; Pectate

\section{Introduction}

Enzymes are delicate proteins. A large no of bacteria and fungi produced Pectinolytic enzymes and mostly they are plant pathogenic. They uses these enzymes to invade host tissue, other than this these enzymes help in decay of dead organic matter [1]. These enzymes include depolymerizing enzymes and demethoxylating enzymes, Polygalacturonase (EC 3.2.1) is most common depolymerizing enzyme this enzyme catalyze The removal of $\alpha-1,4$ Glycosidic linkage among two galacturonic acid units and it coverts polygalacturonic acid into galacturonic acid, While pectin lyase (EC 4.2.2) enhance $\beta$-elimination reaction between methylated Units [2]. Similarly de-esterifying enzymes include pectin esterases, they remove methyl group from methylated pectin and help in production of methanol and pectin [3].

Naturally, microorganisms have been gifted with enormous ability to produce enzymes. They generate a group of enzymes, which have been oppressed commercially from many years. Cellulose and Pectic substances are most rich carbohydrates present inside plant. Pectin propectin and pectic acid contribute in firmness of plant, Pectin form a complex due to its composition and the other impurities like with some proteins and waxes are amalgamate through the back and side chain of Pectin. Pectin mortifying enzymes are formed in huge amount by plant related Microbes. Naturally, there are three main types of pectin mortifying enzymes: pectin Esterases, polygalacturonases and lyases. Pectin esterase (EC3.1.1.11) catalyzes removal of the methyl faction of pectin from pectic acid. Polygalacturonases are a set of biological catalyst which hydrolyze $\alpha-1,4$ glycosidic Linkage in pectin. Due to difference in their way of action pectinases are classified into different type'spolygalacturonase, pectinlyase and pectin esterase. The Lyase cleave polygalacturonate or pectin chains marks in the configuration of a double Bond linking carbon no 4 and carbon no 5 at the non-reducing site with eradication of carbon dioxide. Pectic substances are made up of D-galacturonic acid units connected by $\alpha-1,4$ - glycosidic bond [4].
PG is further classified in to EPG and exopolygalacturonase. Endopolygalacturonase belongs to family 28 glycosyl hydrolase catalysis the internal a 1-4 glycosidic linkage and convert pectic substances into their monomeric form. PG is broadly used in food industries and help in grinding, liquefaction and mining out fruit juices [5]. In industries, Aspergillus neiger is mostly use for the profitable production of PG [6] and only some studies are existing for the manufacture of PG from bacteria [7-9]. Most of the pectinases produced by fungi have most favourable $\mathrm{pH}$ variety between acidic ranges. This $\mathrm{pH}$ range is appropriate for fruit juices, because fruit juices have same optimum $\mathrm{pH}$ range, but these enzymes cannot be used for the vegetable or the other measures for which neutral $\mathrm{pH}$ is required [9].

Endopolygalacturonase is broadly dispersed in fungi like yeast higher plants and Microorganisms [10]. The main source for the pectin degrading enzymes is yeast, bacteria and a large variety of filamentous fungi, for which the most common one is Aspergillus. Bacterial pectin degrading enzymes are present in different classes of Bacillus [11], Amycolata [12] Aspergillus Benen Decompose pectin randomly [10]. Even though the production of some pectin degrading enzymes is possible, at hand still production of enzymes is required with elevated activity and stability at basic environment. Pectin degrading enzymes were most common enzymes which were used at home. People were unaware of their importance on industrial scale. First of all their industrial uses was highlighted in 1930 for the

*Corresponding author: Nayab Munir, Department of Biochemistry and Biotechnology, PMAS Arid Agriculture University Rawalpindi, Pakistan, Tel: +92-051-9290466; E-mail: nayab.munir@yahoo.com

Received: April 24, 2015; Accepted: May 20, 2015; Published May 22, 2015

Citation: Munir N, Asad MJ, Haidri SH (2015) Production, Purification and Characterization of Endopolygalacturonase by Bacillus subtillus. Biochem Anal Biochem 4: 181. doi:10.4172/2161-1009.1000181

Copyright: (c) 2015 Munir N. This is an open-access article distributed under the terms of the Creative Commons Attribution License, which permits unrestricted use, distribution, and reproduction in any medium, provided the original author and source are credited. 
production of wines and fruit juices. After 1960 when scientist came to know about chemical composition of plant tissue requirement for production of these enzymes increases, scientists start to utilize a larger variety of enzymes more proficiently. As a consequence, pectinases are most popular enzymes of the profit-making. First and foremost, these enzymes were accountable for the breakdown of the extended and composite substances known as pectin that is polysaccharides present in middle lamella and the primary call walls of young plant. Pectin degrading enzymes are at this time an essential part of fruit juice and textile industries. The objectives of adding enzymes differ in different kinds of fruit and vegetable juices. If juice is dazzling clear enzymes are required to increase the juice quantity. In some cases enzyme is added throughout pressing and straining in order to eliminate floating substances and clear juice is obtained [13].

Apple juice is prepared as natural, unaltered and unclarified, juice consist of high quantity of mash it is unclear juice. We centrifuged it to take away suspended particles but not altered; and at the end filtered plain and yellowish-brown-colored juice form by adding enzyme [14]. Even though pectin degrading enzymes can depolymerize highly esterified pectin are the main types of enzymes required for production of clear apple juice [15].

Clarification of juice is dependent on $\mathrm{pH}$, temperature and quantity of enzyme. We can easily clarify juice if $\mathrm{pH}$ is in acidic range. Similarly if temperature raises juice clarification become more and more easy but temperature cannot be higher than denaturation temperature of enzyme [14].

Clarification of apple juice possibly will be obtained by using mixture of pectin degrading enzymes like PG and PME [16]. Pectin enzymes are useful in wine making $[17,18]$. The improve deliberation of anthocyanin through red grapes into the juice by adding pectin enzymes is another benefit of these enzymes [13].

Agricultural resources of fermentable carbohydrates must be processed to get fermentable sugar like sugar beet; sugarcane, wheat and potatoes etc. Huge amount of plant cell-wall resources happen to accessible as by products in the beet-sugar and starch factories. Pectinases along with cellulase enzymes and hemicellulases is required for the manufacturing fermentable sugars from polysaccharides and for the breakdown of cell wall matrix, so liquefy the substances and the liberate carbohydrates present inside cell [19]. More emphasis is laid on production of high yielding strains [20]. Bacillus subtilis will be used for production of endopolygalacturonase it is sporullating, aerobic gram positive strain. This bacterium is non virulent. But this bacterial specie sometime may cause secondary infection and during storage they can produce soft-rot symptoms in some plant [21].

\section{Material and Method}

\section{Selection of bacterial strain}

Pure strain of the Bacillus subtillus was brought from; University of Waterloo Canada It was sub cultured after every three month on YUP medium and preserved it in refrigerator having temperature $4^{\circ} \mathrm{C}$. New cultures were prepared every time whenever there was need for preparing inoculum.

\section{Substrate preparation}

Different agro-wastes like peels of citrus fruits, apple and radish were used as substrates for the production of the endo-PG. peels were collected from fruit juice shops from local market of Rawalpindi. The substrates was firstly sun dried and then in oven at $70^{\circ} \mathrm{C}$ and ground to a fine powder by using electric grinder. The ground substrates were passed through sieve to obtain mesh size of $40 \mathrm{~mm}$ and $80 \mathrm{~mm}$. These ground substrates were used for the production of the endo-PG.

\section{Preparation of Inoculum}

Inoculum of the endo-PG positive bacteria was prepared in inoculum media with a Composition $\left(0.05 \% \mathrm{KCl}, 0.1 \% \mathrm{MgSO}_{4} .7 \mathrm{H}_{2} \mathrm{O}\right.$, $0.1 \%$ tri-sodium citrate dehydrate, $0.5 \%$ yeast extract, $0.5 \%$ tryptone) $[9,22]$. Inoculums was prepared by picking cultured bacterial colony with the help of Culturing loop, loop was dipped in inoculums media and the process was repeated In order to get enough concentration of bacterial colony the process was repeated

Medium was shaken for 6 hour for uniform suspension. Then through spreading and culturing inoculum was checked for presence of impurities.0.2 M HCl and $0.2 \mathrm{M} \mathrm{NaOH}$ was used to adjust $\mathrm{pH}$ of inoculum at 6.7 .

\section{Fermentation Chamber for Endopolygalacturonase}

$250 \mathrm{ml}$ Erlenmeyer flasks, containing fermentation materials, placed in Incubator. Then all conditions were set like temperature, time and speed for shaking was adjusted at $170 \mathrm{rpm}$.

\section{The Process of Fermentation}

In each flask as a unit of Fermentation 5 gram substrate and $100 \mathrm{ml}$ of distilled water was taken. At benchmark values of $121^{\circ} \mathrm{C}$ for $20 \mathrm{~min}$ reaction mixture containing substrate was autoclaved for sterilization. Autoclaved substrate was leave for some time to cool down at $37^{\circ} \mathrm{Ctemperature}$ initial quantity of inoculum was poured in reaction mixture in Laminar flow in order to avoid contamination with other microbes and kept back inside incubator further for fermentation. After adding inoculum flasks were placed for shaking at $170 \mathrm{rpm}$ at temperature of $35^{\circ} \mathrm{C}$ for 6 hour. Then after few hours reaction mixture was filtered by using filter paper. The crude extract was stored in refrigerator. Enzyme activity was determined within 24 Hours of the filtered extract.

\section{Standard Curve for Galacturonic Acid}

Standard curve for galacturonic acid was prepared by taking OD of different concentration of galacturonic acid at $640 \mathrm{~nm}$. It was used to calculate the galacturonic acid produced by Endopolygalacturonase.

\section{Enzyme Assay Protocol for Epg}

The different amounts of endopolygalacturonase obtained after completion of fermentation process were approximate by measuring amount of galacturonic acid produced by endopolygalacturonase after reacting with Polygalacturonic acid. For that purpose polygalacturonic acid was added in reaction mixture along with crude enzyme. Crude enzyme was dissolved in phosphate buffer having $\mathrm{pH}$ of 4.8. Control was prepared by adding polygalacturonic acid $\mathrm{D} . \mathrm{H}_{2}$

$\mathrm{O}$ and buffer. After complete mixing of all these things test mixture and control both was placed in incubator at $37^{\circ} \mathrm{C}$ for 20 minutes then $0.1 \mathrm{ml}$ DNS was added in all test tubes and keep it at $100^{\circ} \mathrm{C}$ or boiling water bath for few minutes [23]. After completing this process OD of control was measure by using spectrophotometer at $640 \mathrm{~nm}$ and converted in to zero after that OD of test mixture was measure at same wavelength. 


\section{Preparation of DNS Solution}

$2 \mathrm{ml}$ of DNSA reagent solution A (Table 1) was poured in $2 \mathrm{~mL}$ solution of sugar in $20 \mathrm{ml}$ flask. The flask was kept in boiling water for 15 minutes. After 15 minutes with gape of few minutes, $0.5 \mathrm{ml}$ of solution B was poured in flask and kept for some time to cool down at room temperature.

\section{Equations Used to Calculate Enzyme Activity}

Enzyme activity was calculated in terms of the quantity of products formed by conversion of Substrate. The unit of enzyme activity was defining as micromole of galacturonic Acid released after 1 minute. It was calculated by the following formulas.

$$
\text { Enzyme activity }=\frac{\text { Absorbance } \mathrm{X} \text { standerd factor } \mathrm{X} \text { dilution factor }}{\text { Time of incubation }}
$$

Dilution factor=amount of water in $\mathrm{ml}$ which was added in flask.

Standard factor $=\underline{\text { Concentration of Standard }(\mu \mathrm{Mol} / \mathrm{ml})}$

Absorbance of Standard

$$
\text { Specific activity of enzyme }=\frac{\text { Enzyme activity }}{\text { Protein content }(\mathrm{mg})}
$$

\section{Optimization of Different Parameters for the Production of Endo-Pg}

It is very important to check individual response of any condition on enzyme activity during process of fermentation for unbeaten optimization; for those purpose different experiments was conducted in order to study effect of different environmental conditions on enzyme production. At a time effect of two factors was studied, maintaining all others conditions at constant value by using Response surface methodology (RSM).

\section{Optimization of inoculum size and age}

\begin{tabular}{|c|c|c|}
\hline NO & Component & Quantity (g) \\
\hline \multicolumn{3}{|c|}{ Solution A } \\
\hline 1 & Distilled water & To make final volume up to $500 \mathrm{~m}$ \\
\hline 2 & Dinitroisilicyclic acid & $5 \mathrm{mg}$ \\
\hline 3 & Phenol & $1.5 \mathrm{ml}$ \\
\hline 4 & Sodium Sulfite & $0.25 \mathrm{mg}$ \\
\hline 5 & Sodium Hydrooxide & $5 \mathrm{mg}$ \\
\hline \multicolumn{3}{|c|}{ Solution b } \\
\hline 1 & Distilled water & To make final volume up to $100 \mathrm{~m}$ \\
\hline 2 & Rochelle Salt & $40 \mathrm{mg}$ \\
\hline
\end{tabular}

Inoculum was prepared by the method of [22]. inoculum media

Table 1: Composition of DNS Solution.

\begin{tabular}{|c|c|}
\hline Inoculum size (ml) & Inoculum age (hour) \\
\hline 0.95 & 16 \\
\hline 6.25 & 16 \\
\hline 10 & 8 \\
\hline 6.25 & 27.31 \\
\hline 10 & 24 \\
\hline 2.25 & 4 \\
\hline 11.55 & 8 \\
\hline 2.50 & 16 \\
\hline
\end{tabular}

Table 2: Effect of Inoculum Size and Inoculum Age on Enzyme production.

\begin{tabular}{|c|c|}
\hline Temperature $\left({ }^{\circ} \mathbf{C}\right)$ & Ph \\
\hline 9 & 5 \\
\hline 30 & 3 \\
\hline 19 & 5 \\
\hline 55 & 7.8 \\
\hline 80 & 3 \\
\hline 55 & 2.17 \\
\hline 30 & 7 \\
\hline 55 & 5 \\
\hline
\end{tabular}

Table 3: Effect of Temperature and $\mathrm{pH}$ on Enzyme production.

will be placed for shaking for 8, 12, 16 hour inoculum of different sizes were used for the optimization of inoculum size $2.5 \%, 5 \%, 10 \%$ [9].

Loop containing bacterial colony was transferred to the inoculum media and the media was placed for shaking at $160 \mathrm{rpm}$ for different time intervals $(8,12$, and 16,20 and 24 hours) to get an optimum time period. The time period giving the maximum endo-PG production will be used in next experiments [9]. Combine result for size and age of inoculum was determined by applying RSM. RSM provide different combinations of Inoculum size and age mentioned in Table 2.

\section{Substrate water ratio and fermentation period}

Substrate was used in different ratios $(1 \%, 2 \%, 3 \%, 4 \%$ and $5 \%)$ with the distilled water in the production media to get an optimum substrate-water ratio. Growth media containing the inoculum and the substrate was placed on shaking for different time intervals $(24,48$, and 72, 96 and 120 hours) to obtain the optimum fermentation period [9]. RSM was applied to get result.

\section{Optimization of fermentation temperature and $\mathrm{pH}$}

The growth media having different $\mathrm{pH}$ values 2 to 7 was made and each was tested for the endo-PG production and the optimum growth $\mathrm{pH}$ was determined 2, 3, 5, 7 and 8 [9]. It was adjusted by adding $1 \mathrm{mM}$ $\mathrm{HCl}$ and $\mathrm{NaOH}$ in crude extract. Other surroundings of the experiment were kept same as preliminary conditions. The $\mathrm{pH}$ of control was kept at 6.4 because inoculum was 6.4 without any adjustment. The growth media was placed for shaking at different temperatures $(30,40,50,60$, 70 and 80) shown in Table 3.

\section{Effect of Inducers/Inhibitors}

\section{Carbon sources and nitrogen sources}

Fructose, galactose, lactose and sucrose will be used as carbon sources. They were used in different concentrations $(0.5 \%, 1 \%, 1.5 \%$, $2 \%$ and $2.5 \%$ ) to find an optimum concentration [9]. Ammonium sulfate, ammonium nitrate, ammonium chloride and calcium nitrate will be used as nitrogen sources. Different concentrations $(0.5 \%, 1 \%$, $1.5 \%, 2 \%$ and $2.5 \%$ ) of nitrogen will be prepared and the optimum concentration will be determined [9]. Different combinations of carbon and nitrogen sources were used along with different concentration by application of RSM (Tables 4-7).

\section{Surfactants and mediator}

Tween-20, tween-80 and SDS was used as source of surfactants. Their different concentrations were used $(0.5 \%, 1 \%, 1.5 \%, 2 \%$ and $2.5 \%)$.

Urea, yeast extract, peptone and cane molasses will be used as mediators. Different concentrations $(0.5 \%, 1 \%, 1.5 \%, 2 \%$ and $2.5 \%)$ of 
Citation: Munir N, Asad MJ, Haidri SH (2015) Production, Purification and Characterization of Endopolygalacturonase by Bacillus subtillus. Biochem Anal Biochem 4: 181. doi:10.4172/2161-1009.1000181

\begin{tabular}{|c|c|}
\hline Fructose (g) & Ammonium sulfate $(\mathbf{g})$ \\
\hline 1.5 & 1.5 \\
\hline 2.914 & 1.5 \\
\hline 1.5 & 0.085 \\
\hline 2.5 & 2.5 \\
\hline 0.5 & 2.5 \\
\hline 1.5 & 2.914 \\
\hline 2.5 & 0.5 \\
\hline 0.085 & 1.5 \\
\hline
\end{tabular}

Table 4: Effect of Fructose and Ammonium Sulfate on Enzume production.

\begin{tabular}{|c|c|}
\hline Lactose & Ammonium nitrate \\
\hline 1.5 & 1.5 \\
\hline 2.914 & 1.5 \\
\hline 1.5 & 0.085 \\
\hline 2.5 & 2.5 \\
\hline 0.5 & 2.5 \\
\hline 1.5 & 2.914 \\
\hline 2.5 & 0.5 \\
\hline 0.085 & 1.5 \\
\hline
\end{tabular}

Table 5: Effect of Lactose and Ammonium Nitrate on Enzyme production.

\begin{tabular}{|c|c|}
\hline Galactose & Ammonium chloride \\
\hline 1.5 & 1.5 \\
\hline 2.914 & 1.5 \\
\hline 1.5 & 0.085 \\
\hline 2.5 & 2.5 \\
\hline 0.5 & 2.5 \\
\hline 1.5 & 2.914 \\
\hline 2.5 & 0.5 \\
\hline 0.085 & 1.5 \\
\hline
\end{tabular}

Table 6: Effect of Galactose and Ammonium Chloride on Enzyme production.

\begin{tabular}{|c|c|}
\hline Sucrose & Calcium Nitrate \\
\hline 1.5 & 1.5 \\
\hline 2.914 & 1.5 \\
\hline 1.5 & 0.085 \\
\hline 2.5 & 2.5 \\
\hline 0.5 & 2.5 \\
\hline 1.5 & 2.914 \\
\hline 2.5 & 0.5 \\
\hline 0.085 & 1.5 \\
\hline
\end{tabular}

Table 7: Effect of Sucrose and Calcium Nitrate on Enzyme production.

\begin{tabular}{|c|c|}
\hline Cane Molases $(\mathbf{m l})$ & Tween $\mathbf{8 0}(\mathbf{m l})$ \\
\hline 2.5 & 2.5 \\
\hline 0.5 & 2.5 \\
\hline 0.5 & 0.5 \\
\hline 1.5 & 0.085 \\
\hline 1.5 & 1.5 \\
\hline 1.5 & 2.914 \\
\hline 0.085 & 1.5 \\
\hline 2.914 & 1.5 \\
\hline 2.5 & 0.5 \\
\hline
\end{tabular}

Table 8: Effect ofCane molases and Tween 80 on Enzyme production. mediators will be used. Combine effect of surfactant and mediator was studied by using RSM (Tables 8-10).

\section{Metal ions}

Calcium chloride, magnesium chloride and zinc chloride will be used as metal ion sources. Different concentrations $(0.5,1.0,1.5,2.0$, $2.5 \mathrm{mM}$ ) of calcium chloride and magnesium chloride and different concentrations $(1.0,1.5,2.0,2.5,3.0 \mu \mathrm{M})$ of zinc chloride will be used (Table 11).

\section{Enzyme Purification}

\section{Partial purification of endopolygalacturonase}

Ethanol, acetone and isopropanol were used as organic solvents in different ratios with the crude extract (10:90, 20:80; 30:70; 40:60; 50:50; $60: 40) .10 \%$ organic solvent and $90 \%$ crude enzyme was added in $1^{\text {st }}$ test tube then $20 \%$ organic solvent and $80 \%$ crude extract was added in $2^{\text {nd }}$ test tube and so on up to $60 \%$ organic solvent and $40 \%$ crude extract in last test tube and then enzyme activity was done for both pallet and supernatant.

\section{Partial purification by ammonium sulphate}

Different concentrations taking start from $10 \%$ then $20 \%, 30 \%$, $40 \%, 50 \%, 60 \%$ of ammonium sulfate with that of the crude enzyme

\begin{tabular}{|c|c|}
\hline Peptone $(\mathbf{g})$ & SDS $(\mathbf{g})$ \\
\hline 2.5 & 2.5 \\
\hline 0.5 & 2.5 \\
\hline 0.5 & 0.5 \\
\hline 1.5 & 0.085 \\
\hline 1.5 & 1.5 \\
\hline 1.5 & 2.914 \\
\hline 0.085 & 1.5 \\
\hline 2.914 & 1.5 \\
\hline 2.5 & 0.5 \\
\hline
\end{tabular}

Table 9: Effect of Peptone and SDS on Enzyme production.

\begin{tabular}{|c|c|}
\hline Tween 20 (ml) & Yeast Extract $\mathbf{( g )}$ \\
\hline 2.5 & 2.5 \\
\hline 0.5 & 2.5 \\
\hline 0.5 & 0.5 \\
\hline 1.5 & 0.085 \\
\hline 1.5 & 1.5 \\
\hline 1.5 & 2.914 \\
\hline 0.085 & 1.5 \\
\hline 2.914 & 1.5 \\
\hline 2.5 & 0.5 \\
\hline
\end{tabular}

Table 10: Effect of Tween 20 and yeast extract on enzyme production.

\begin{tabular}{|c|c|}
\hline Calcium chloride & Magnesium chloride \\
\hline 2.5 & 2.5 \\
\hline 0.5 & 2.5 \\
\hline 0.5 & 0.5 \\
\hline 1.5 & 0.085 \\
\hline 1.5 & 1.5 \\
\hline 1.5 & 2.914 \\
\hline 0.085 & 1.5 \\
\hline 2.914 & 1.5 \\
\hline 2.5 & 0.5 \\
\hline
\end{tabular}

Table 11: Effect of Calcium Chloride and Magnesium Chloride on E.A. 
was used for the partial purification of the endo-PG and its activity for each concentration was determined.

\section{Gel filtration}

Gel filtration was carried-out to further purify the enzyme. Sephadex G-100 was used for gel purification. The column of $1.5 \times$ 60 dimension was used. The dry Sephadex powder was dissolved in phosphate buffer and we leave it for some time and wait for swelling of gel. After swelling of gel it was shacked for few minutes. After few hours supernatant was removed and same process was repeated for Several times, a burette was used as column it was $3 \mathrm{~cm}$ in diameter and $50 \mathrm{~cm}$ in Length, before packing of column burette was firstly washed with tape water and Then with phosphate buffer having same $\mathrm{pH}$ 4.8. A small piece of wool was placed at the end of column and funnel was placed at top of column. Firstly simple buffer was passed through column and then Sephadex swollen buffer was added in column. Bottom outlet was open and when suspended particles reach at bottom of column. After the complete packing of martial funnel was removed, few $\mathrm{ml}$ of buffer were Allowed to enter the column to avoid dryness of column, sample was added drop By drop and different frictions were collected and their $\mathrm{OD}$ was taken at $280 \mathrm{~nm}$. The endo-PG after the gel filtration will be run on polyacrylamide gel electrophoresis (PAGE) to check the purity of the enzyme.

\section{Enzyme Characterization}

\section{Effect of temperature and $\mathrm{pH}$ on EPG production}

The outcome of temperature and $\mathrm{pH}$ on the production of enzyme was measure by carrying enzyme assay at different ranges of temperatures between $30-80^{\circ} \mathrm{C}$ and optimum temperature was determined for enzyme assay. By using buffer of diverse $\mathrm{pH}$ values from 5 to 9 was used for the enzyme assay to determine the optimum $\mathrm{pH}$ of the endo-PG [24].

\section{Effect of substrate concentration}

Substrate of different concentrations was used to find-out Kmax and Vmax. Line weaver Burk plot will be made to find-out the Kmax and Vmax.

\section{Molecular weight determination}

The purified endo-PG after the gel filtration will be run on SDSPAGE to find-out its molecular weight.

\section{Statistical analysis}

All the data after complete optimization was arrange by applying ANOVA under completely randomized design (CRD) Treatment mean of different parameters was compared by Duncan's multiple range test (DMRT) (Steel et al., 1997).

\section{Result and Discussion}

\section{Standard Curve for Galacturonic Acid}

Standard curve of galacturonic acid was made by using its different concentrations. The regression equation, $\mathrm{y}=0.004 \mathrm{x}-0.005$ was inserted by using Microsoft Excel ' $y$ ' was equal to concentration of Galacturonic acid in $\mu \mathrm{g} / \mathrm{mL}$ and ' $\mathrm{x}$ ' was $\mathrm{OD}$ at $640 \mathrm{~nm}$ (Figure 1).

\section{Production of endopolygalacturonase from Bacillus subtillus}

Bacillus subtillus is strain of bacteria which have great potential for production of endopolygalacturonase. According to previous research
PG produced by Bacillus subtillus shows very high enzyme activity as compare to Aspergillus Niger.

EPG was produced by using citrus peels, apple peels and radish peels. Maximum enzyme was produced when citrus peels were used as carbon source. After citrus peels apple peels show high enzyme activity. Fur further optimization of different parameters citrus peels were selected as substrate. It was concluded that citrus peels are good substrate for production of EPG (Table 12 and Figure 2).

\section{Optimization of Different Factors}

Different parameters were optimized by using response surface methodology.

\section{Optimization of F.P and substrate water ratio}

Enzyme activity was done at different fermentation period and

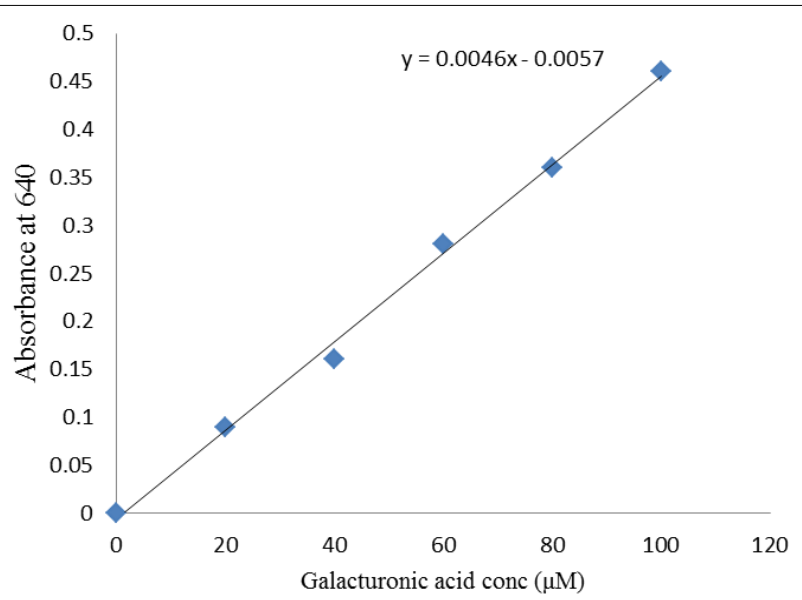

Figure 1: Standerd curve of galacturonic acid.

\begin{tabular}{|l|c|c|c|c|c|}
\hline Source & DF & SS & MS & F-Value & P-Value \\
\hline Concentration of substrate & 1 & 15692 & 15691.8 & 24.54 & 0.00 \\
\hline OD & 4 & 2557 & 639.4 & & \\
\hline enzyme activity & 5 & 18249 & & & \\
\hline S=25.2854 $\mathrm{R}^{2}=85.99 \%$ & \multicolumn{5}{|l}{} \\
\hline
\end{tabular}

Table 12: ANOVA showing the effect of different substrates on enzyme production.

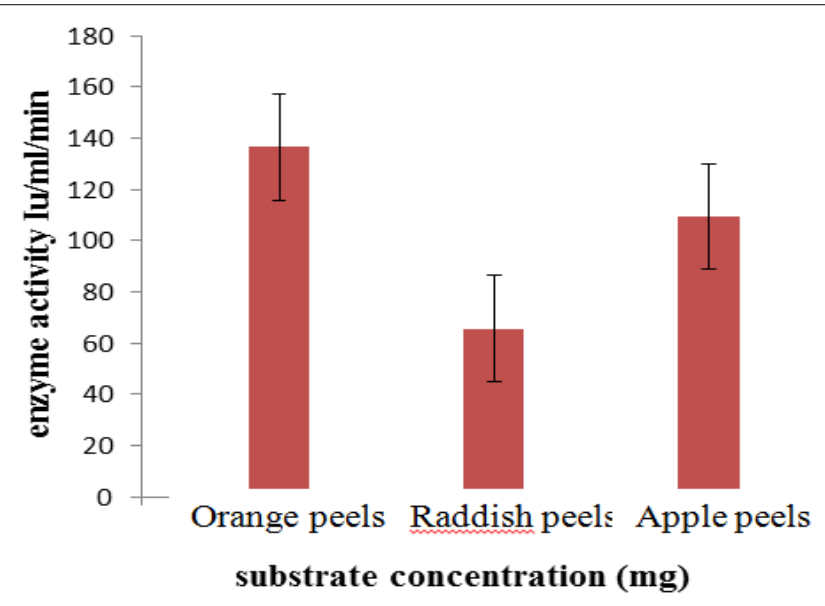

Figure 2: Production of EPG by using different substrates. 
substrate water ratio. Maximum enzyme activity was observed at fermentation period of 24 hour and 5\% substrate water ratio which is in accordance with previous results shown by Figures 3 and 4 .

\section{Optimization of inoculum size and age}

Enzyme activity was measure by adding inoculum of different size and age. Maximum enzyme activity was observed at inoculum size of $11.9 \mathrm{ml}$ and inoculum age of 16 hour as shown by Figures 4 and 5 .

\section{Temperature and $\mathrm{pH}$}

When fermentation was done at different temperature pronounced effect of temperature was observed at enzyme activity. With the increase of temperature enzyme activity also increases and maximum enzyme concentration was measure at temperature of $60^{\circ} \mathrm{C}$ and $80^{\circ} \mathrm{C}$. Similarly effect of $\mathrm{pH}$ was also observed and maximum enzyme production occurs when $\mathrm{pH}$ of crude extract was 7.8. Figure 6 shows combine effect of temperature and $\mathrm{pH}$.

\section{Effect of inducers/inhibitors}

Combine effect of inducers and inhibitors was study by using response surface methodology.

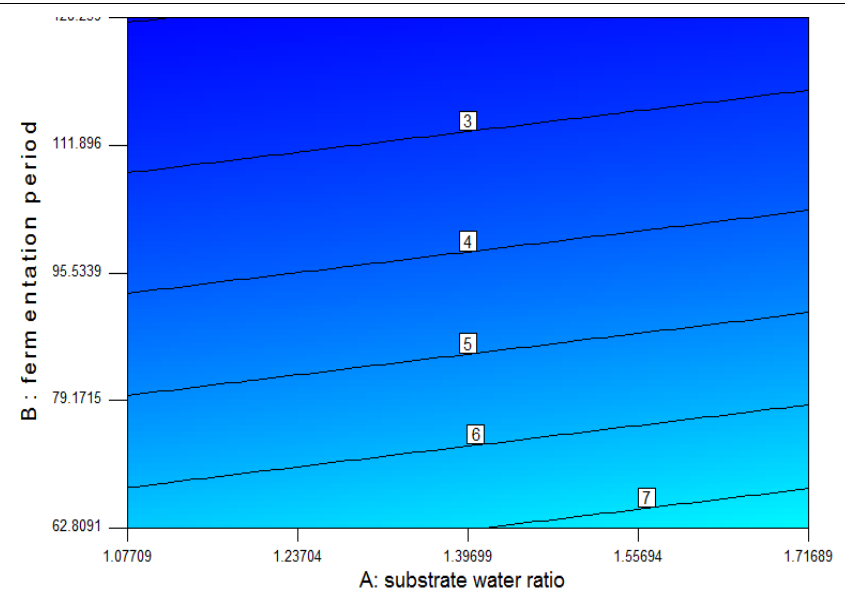

Figure 3: Effect of fermentation period and substrate water ratio on EPG production.

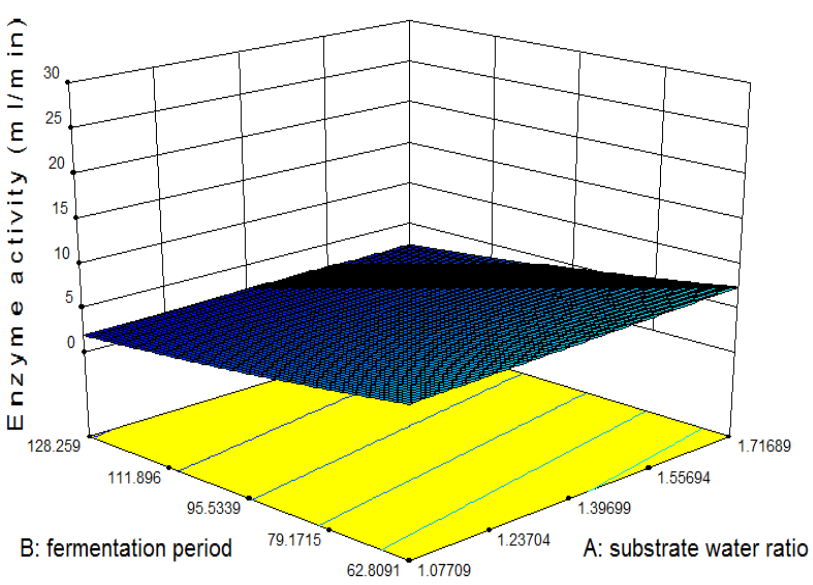

Figure 4: Effect of fermentation period and substrate water ratio on EPG production.

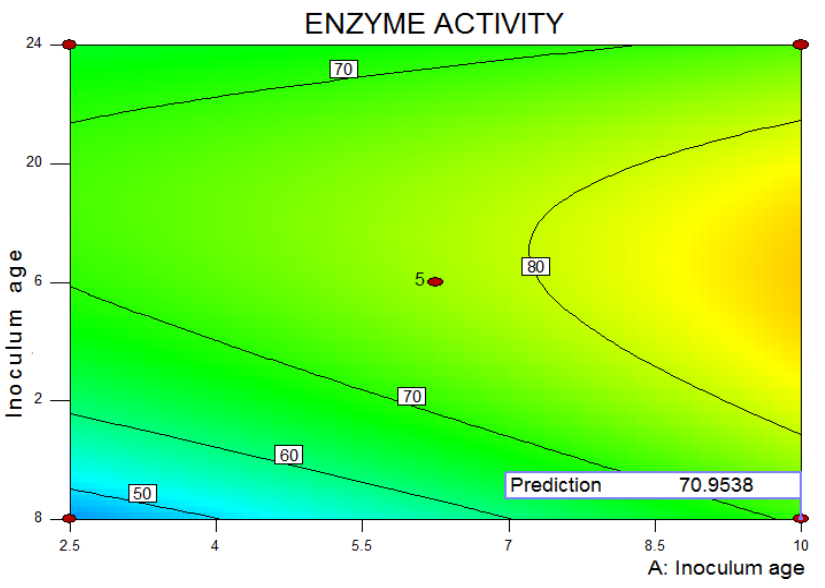

Figure 5: Effect of inoculum size and inoculum age on EPG production.

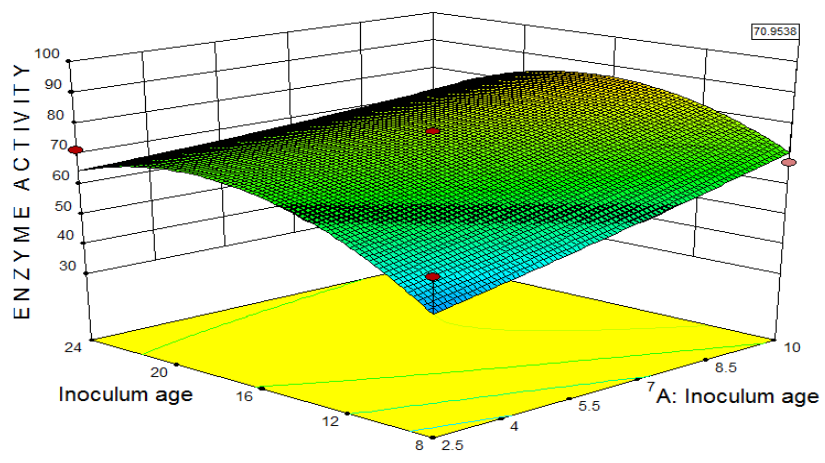

Figure 6: Effect of inoculum size and inoculum age on EPG production.

\section{Carbon sources and nitrogen sources}

Different carbon sources (fructose, sucrose, lactose, galactose) and nitrogen sources (Ammonium sulfate, Ammonium chloride, Ammonium nitrate, calcium nitrate) was added in reaction mixture and after 24 hour of fermentation period at $60^{\circ} \mathrm{C}$ their OD was measured. When ammonium sulfate and fructose was added maximum enzyme activity was observed when concentration of $2.5 \mathrm{mg}$ ammonium sulfate and $2.5 \mathrm{mg}$ fructose. Figures 7 and 8 showing combine effect of Ammonium sulfate and fructose.

Similarly combine effect of lactose and ammonium sulfate was study and maximum enzyme activity was observed when lactose concentration was $2.5 \mathrm{mg}$ and ammonium nitrate concentration was $2.5 \mathrm{mg}$ (Figures 9 and 10).

Combine effect of galactose and ammonium sulfate was observed maximum enzyme activity was observed when ammonium sulfate and galactose concentration was $0.085 \mathrm{mg}$ and galactose concentration was $1.5 \mathrm{mg}$ (Figures 11 and 12). Calcium nitrate and sucrose both have positive effect on enzyme activity and maximum enzyme production was observed when concentration of sucrose and calcium nitrate was $0.5 \mathrm{mg}$ and $2.5 \mathrm{mg}$ (Figures 13 and 14).

Nitrogen and carbon sources repress the enzyme activity and there was no pronounced effect of different carbon and nitrogen sources except calcium nitrate and sucrose in presence of these sources and amplification in enzyme production occur in presence of calcium 
Citation: Munir N, Asad MJ, Haidri SH (2015) Production, Purification and Characterization of Endopolygalacturonase by Bacillus subtillus. Biochem Anal Biochem 4: 181. doi:10.4172/2161-1009.1000181

Page 7 of 12

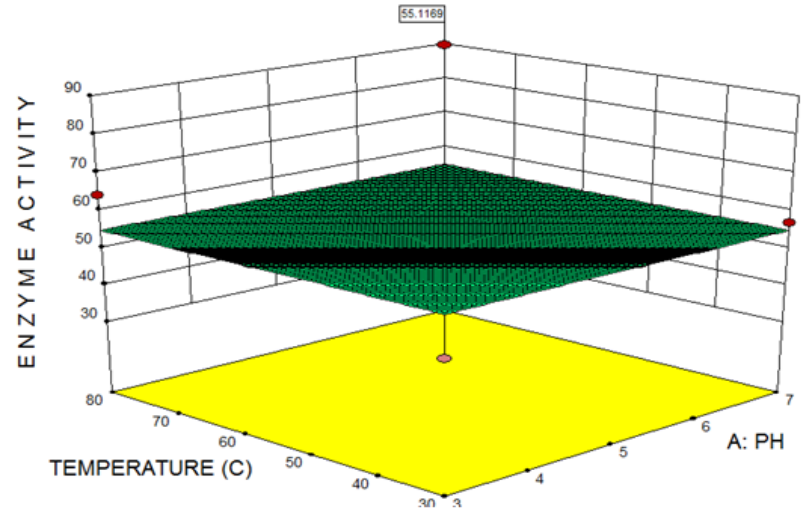

Figure 7: Effect of Temperature and pH on EPG production.

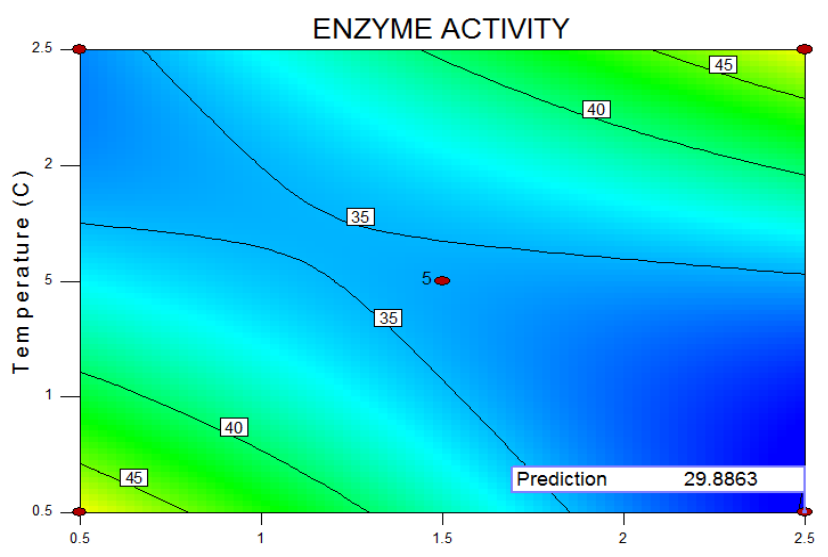

Figure 8: Effect of Ammonium sulfate and fructose on EPG production.

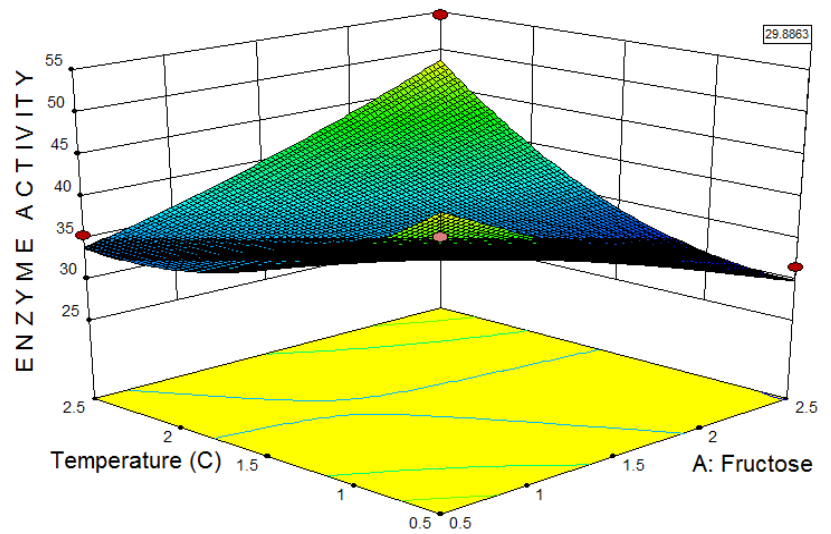

Figure 9: Effect of Ammonium sulfate and fructose on EPG production.

nitrate. When we compare effect of all of the above mention sources among all only in presence of calcium nitrate and sucrose enzyme activity was good. While all other sources decreases the enzyme activity.

\section{Surfactant and mediator}

By adding different surfactant (SDS, Tween 80, Tween 20 ) and mediator( cane molasses changes in enzyme activity was measure mostly these surfactants decrease the enzyme activity except yeast extract and maximum enzyme activity was observe whenever there was increase in concentration of yeast extract and peptone. May be decrease in enzyme activity was observed due to reason that these surfactants was added in combination and they cancel effect of each other and as a result leave negative impact on enzyme production (Figures 15-21).

\section{Result of addition of metal ions}

After adding different metal ions in crude extract their effect on enzyme production was measured. Maximum enzyme activity was observed whenever there was high concentration of calcium chloride. Figures 22 and 23 shows combine effect of $\mathrm{Mgcl}_{2}$ and $\mathrm{Cacl}_{2}$.

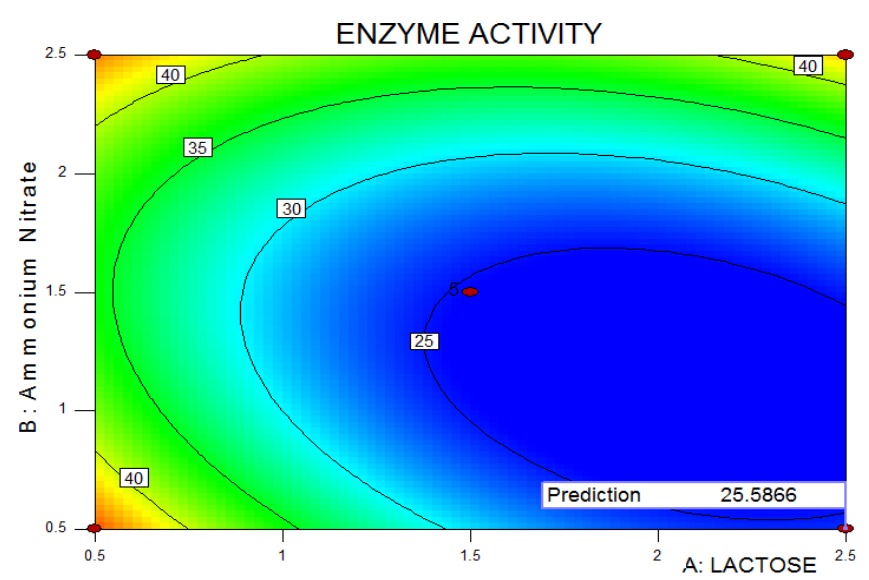

Figure 10: Effect of lactose and ammonium nitrate on EPG production.

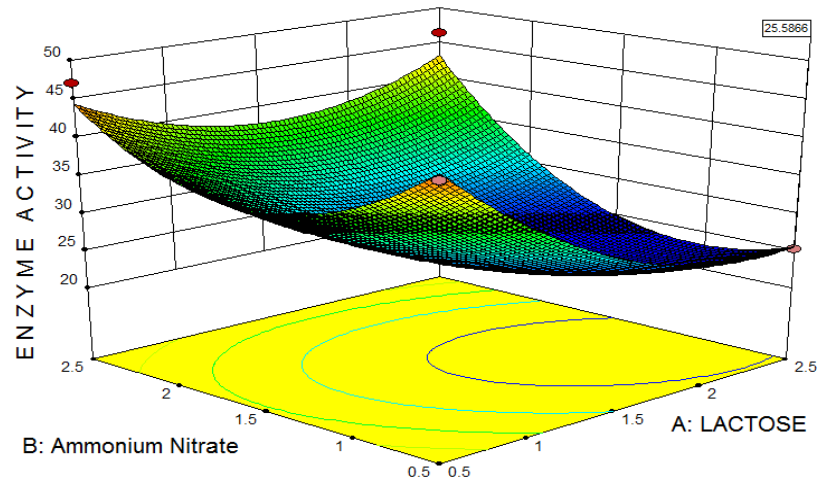

Figure 11: Effect of lactose and ammonium nitarate on EPG production.

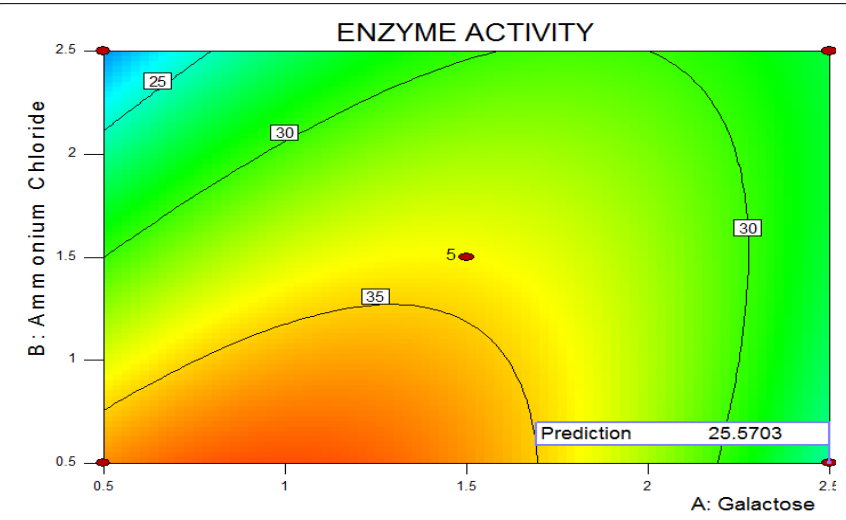

Figure 12: Effect of galactose and ammonium chloride on EPG production. 


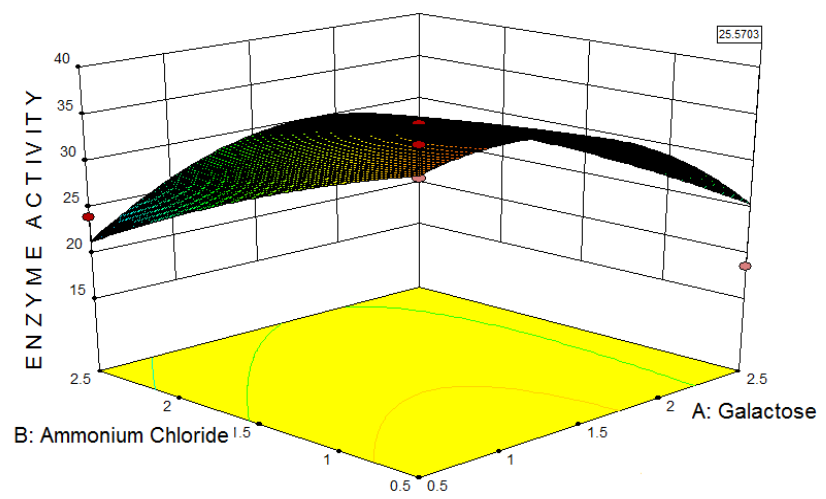

Figure 13: Effect of galactose and ammonium chloride on EPG production.

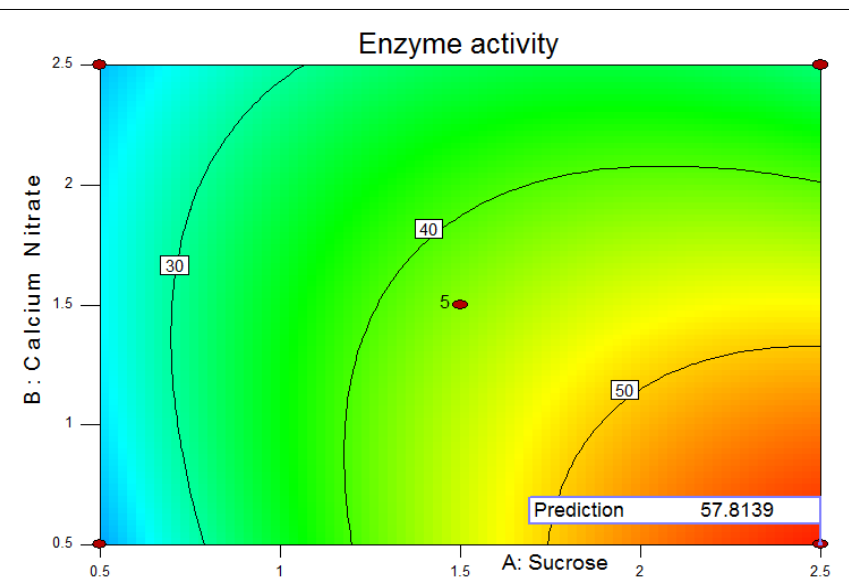

Figure 14: Effect of Sucrose and Calcium Nitrate on EPG production.

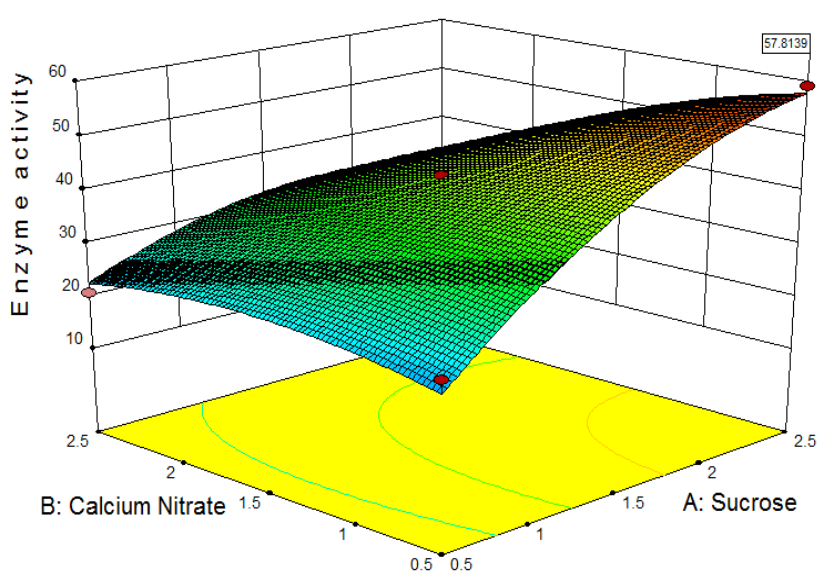

Figure 15: Effect of SDS and Peptone on EPG production.

\section{Enzyme Purification}

Enzyme partial purification was done by using Ammonium sulfate, Ethanol, Methanol, and isopropanol. Maximum enzyme activity was observed with $60 \%$ Ammonium sulfate and $40 \%$ crude extract maximum enzyme activity was $77.4 \mathrm{U} / \mathrm{ml} / \mathrm{min}$ and protein content was 1.168 (Table 13 and Figure 24).

\section{Partial Purification with Organic Solvents}

Partial purification was done by using three organic solvent (methanol, ethanol and isopropanol). Maximum precipitates were observed at $40 \%$ ethanol and $60 \%$ crude extract maximum enzyme was 94.62 and total protein content was 1.01 (Table 14 and Figure 25).

Methanol gives maximum enzyme activity at $30 \%$ methanol and $70 \%$ crude extract. Maximum enzyme activity was 1.11 with protein content of 0.89 (Table 15 and Figure 26). Maximum enzyme activity was observed by using isopropanol. Enzyme activity was 116.7 with protein content of 0.31 (Table 16 and Figure 27).

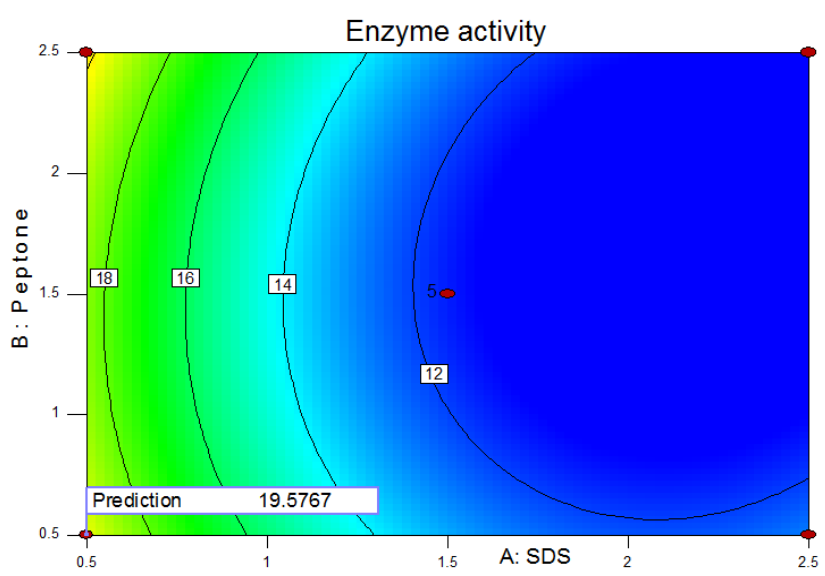

Figure 16: Effect of SDS and petone on EPG production.

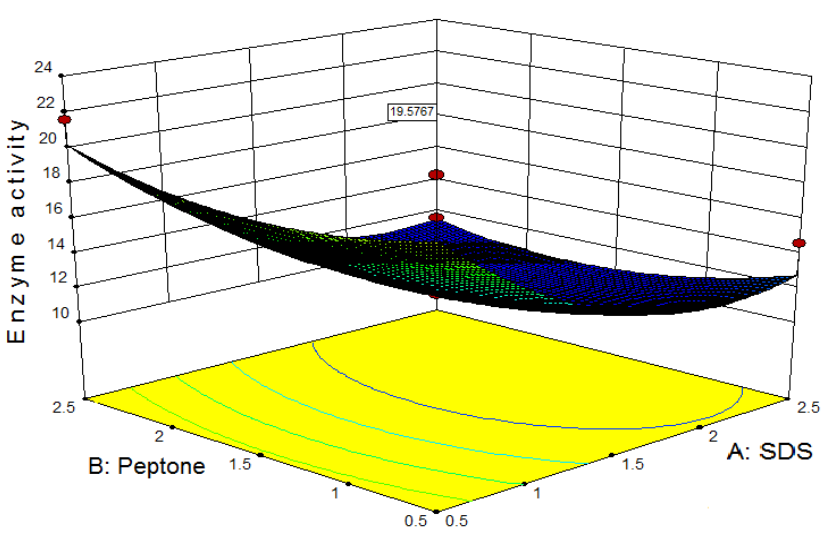

Figure 17: Effect of Cane molasses and Tween 80 on EPG production.

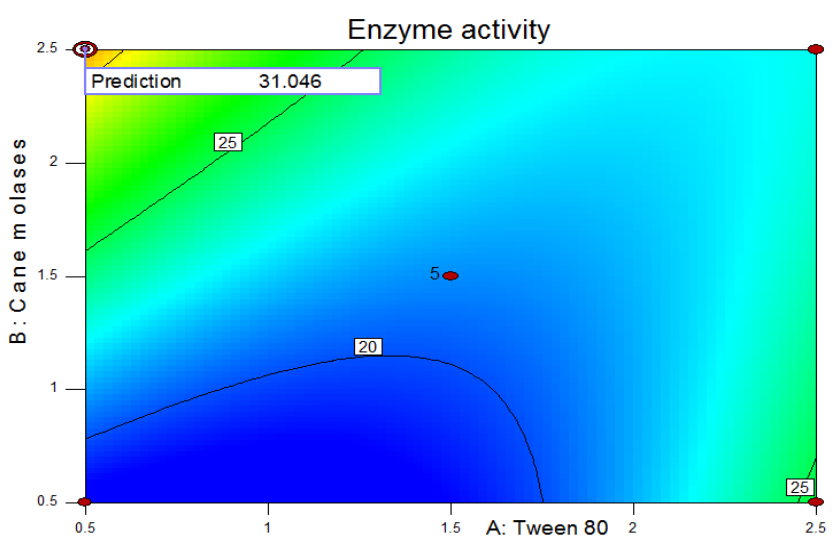

Figure 18: Effect of Cane molasses and Tween 80 on EPG production. 


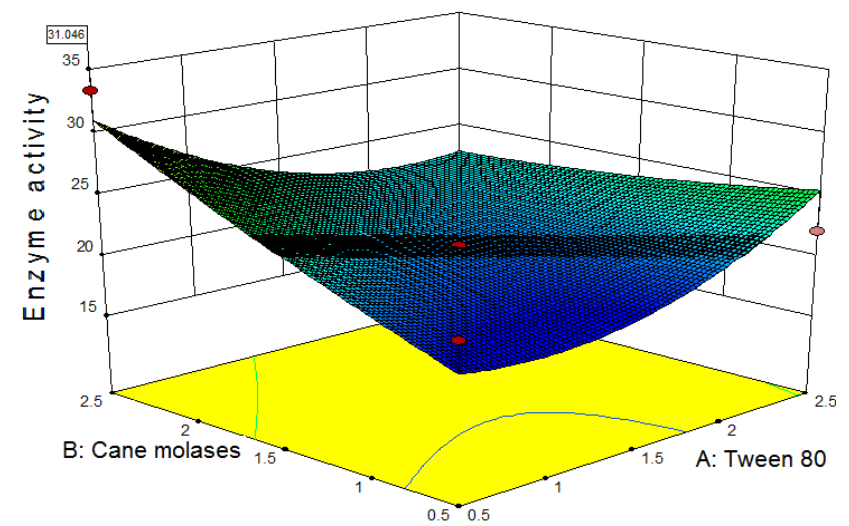

Figure 19: Effect of Tween 20 and yeast extract on EPG production.

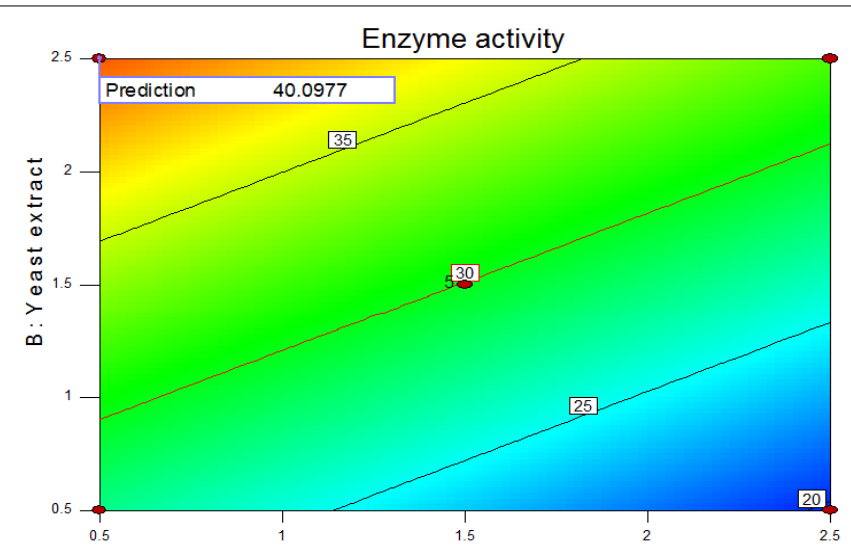

Figure 20: Effect of Tween20 and yeast extract on EPG production.

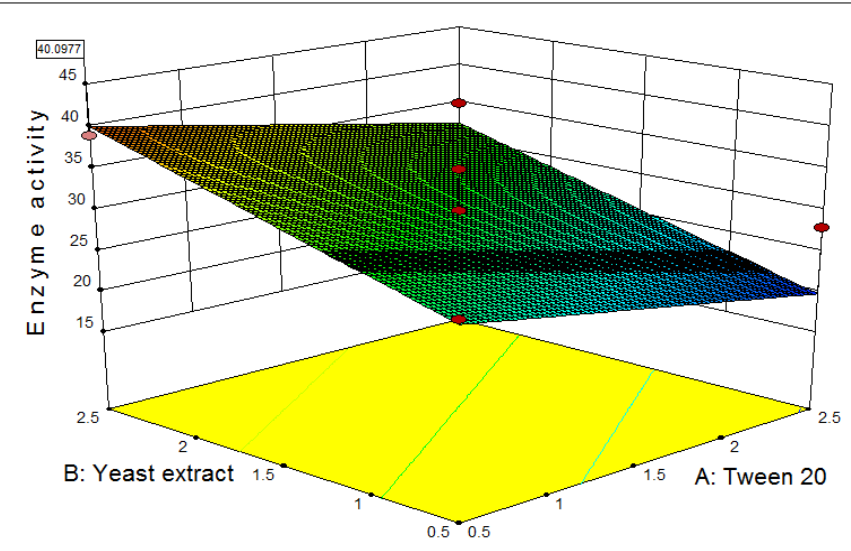

Figure 21: Effect of Tween20 and yeast extract on EPG production.

\section{Gel Filtration}

When partially purified enzyme was run through gel filtration and different friction were collected. Friction no 11, 12 and 13 show highest enzyme activity. Friction 13 shows maximum enzyme activity of 139.91 with protein content of 0.33 (Tables 17, 18, Figures 28 and 29).

\section{Characterization of Endopolygalacturonase}

\section{Effect of $\mathrm{pH}$ on endopolygalacturonase activity}

Maximum enzyme activity was observed by using buffer of PH 5 .
PH 4.8 and 5 show enzyme activity in almost same range so optimum $\mathrm{pH}$ for endopolygalacturonase is 5. Enzyme was stable up to $\mathrm{pH} 9$ (Table 19 and Figure 30). During enzyme assay crude enzyme was placed at different temperatures for 30 minutes and maximum enzyme activity was shown at temperature of $60^{\circ} \mathrm{C}$.

\section{Study of Enzyme Kinatics}

Effect of substrate concentration on EPG :There was increase

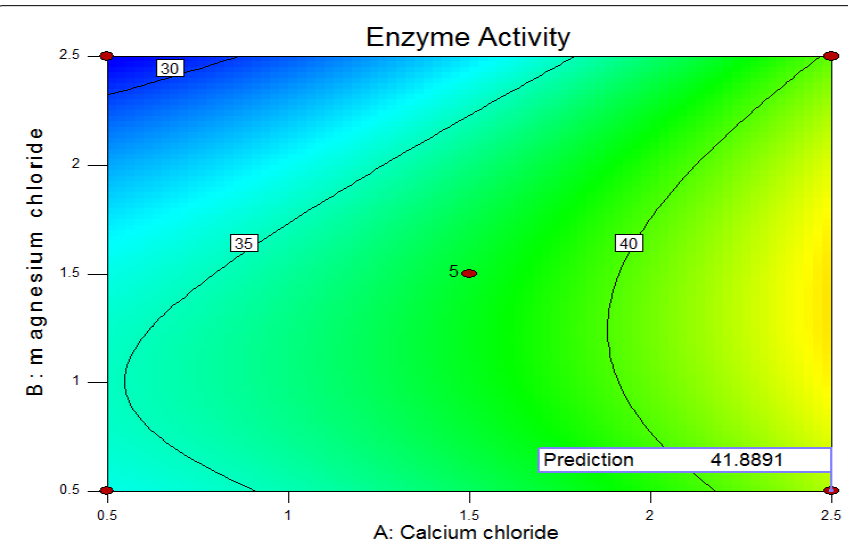

Figure 22: Effect of Magnesium chloride and calcium chloride on EPG production.

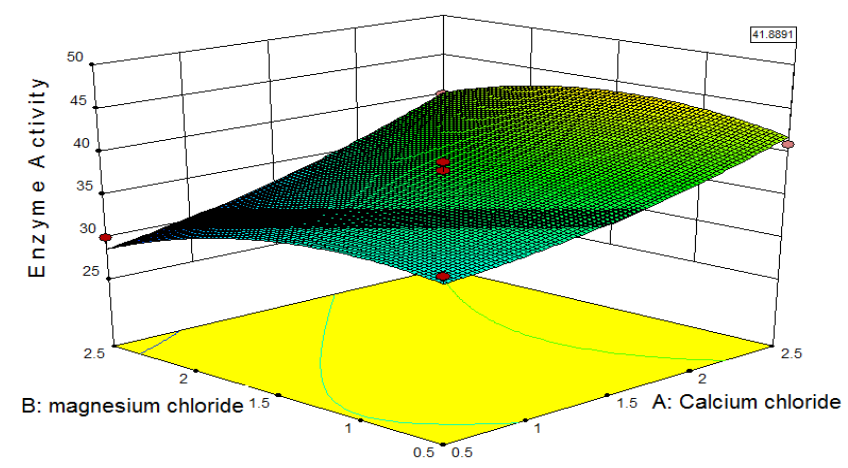

Figure 23: Effect of Mgcl2 and Cacl2 on EPG production.

\begin{tabular}{|l|c|c|c|c|c|}
\hline Source & DF & SS & MS & F-Value & P-Value \\
\hline Concentration of substrate & 2 & 12956 & 6478.2 & 22.73 & 0.00 \\
\hline OD & 21 & 5984 & 285.0 & & \\
\hline enzyme activity & 23 & 18941 & & & \\
\hline S=16.8807 R2 $=65.40 \%$ & & & &
\end{tabular}

Table 13: ANOVA for Enzyme purification with Ammonium sulfate.

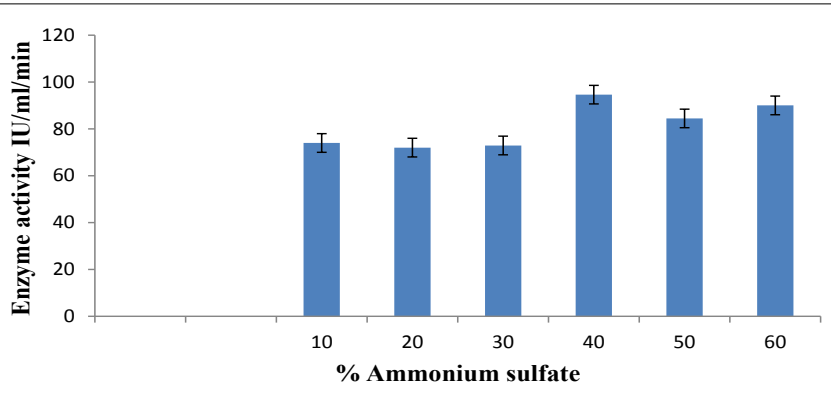

Figure 24: Partial purification of EPG by Ammonium sulfate precipitation. 
Citation: Munir N, Asad MJ, Haidri SH (2015) Production, Purification and Characterization of Endopolygalacturonase by Bacillus subtillus. Biochem Anal Biochem 4: 181. doi:10.4172/2161-1009.1000181

Page 10 of 12

\begin{tabular}{|l|c|c|c|c|c|}
\hline Source & DF & SS & MS & F-Value & P-Value \\
\hline Concentration of substrate & 3 & 22412 & 7470.6 & 37.60 & 0.00 \\
\hline OD & 20 & 3974 & 198.7 & & \\
\hline enzyme activity & 23 & 26386 & & & \\
\hline S=14.0957 $\mathrm{R}^{2}=84.94 \%$ & \multicolumn{3}{|l}{} & & \\
\hline
\end{tabular}

Table 14: ANOVA for Enzyme purification with Ethanol.

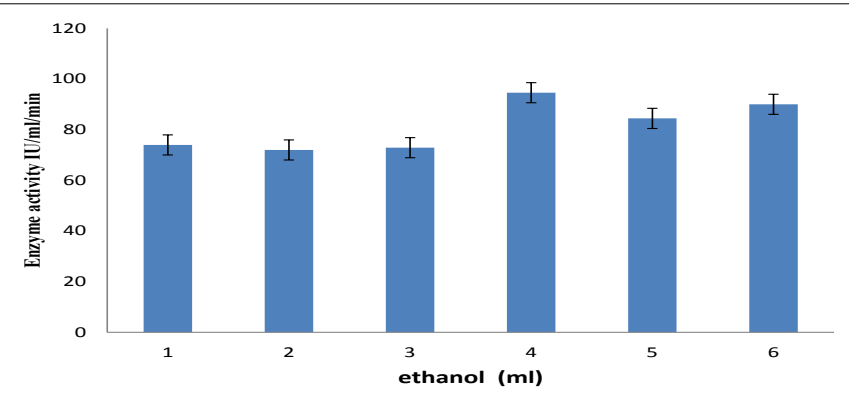

Figure 25: Partial purification of EPG by using ethanol.

\begin{tabular}{|l|c|c|c|c|c|}
\hline Source & DF & SS & MS & F-Value & P-Value \\
\hline Concentration of substrate & 3 & 32631 & 10877.1 & 58.89 & 0.00 \\
\hline OD & 20 & 3694 & 184.7 & & \\
\hline enzyme activity & 23 & 36325 & & & \\
\hline S=13.5903 $\mathrm{R}^{2}=89.83 \%$ & & & &
\end{tabular}

Table 15: ANOVA for purification of enzyme with methanol.

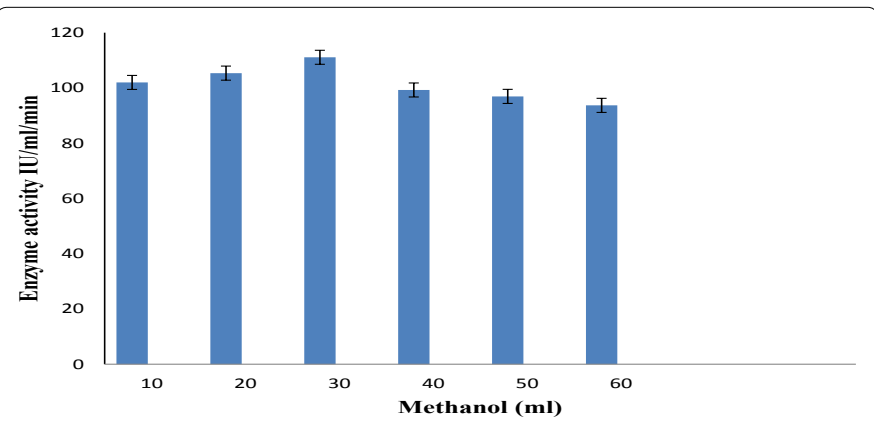

Figure 26: Partial purification of EPG with methanol.

\begin{tabular}{|l|c|c|c|c|c|}
\hline Source & DF & SS & MS & F-Value & P-Value \\
\hline Concentration of substrate & 3 & 24984 & 8328.0 & 30.74 & 0.00 \\
\hline OD & 20 & 5419 & 271.0 & & \\
\hline enzyme activity & 23 & 30403 & & & \\
\hline S=16.4607 $\mathrm{R}^{2}=82.18 \%$ & \multicolumn{3}{|l}{} & & \\
\hline
\end{tabular}

Table 16: ANOVA for Enzyme purification with Isopropanol.

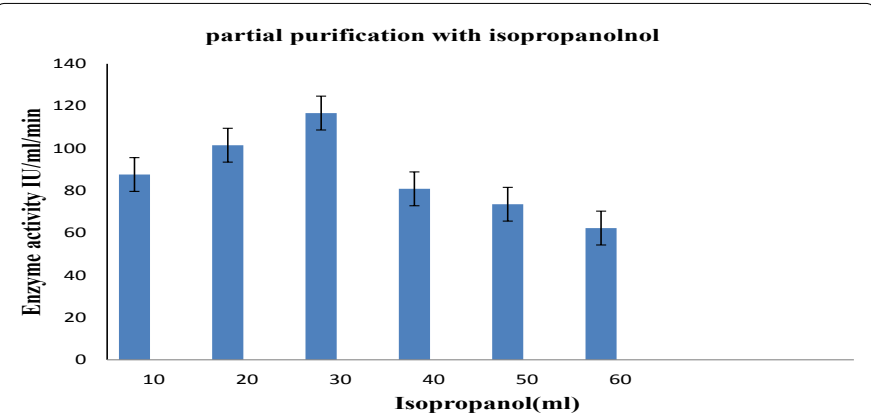

Figure 27: Partial purification of EPG with isopropanol.

\begin{tabular}{|c|c|c|c|c|c|}
\hline Source & DF & SS & MS & F-Value & P-Value \\
\hline Concentration of substrate & 1 & 20637 & 20637 & 16.96 & 0.00 \\
\hline OD & 34 & 41373 & 1217 & & \\
\hline enzyme activity & 35 & 62009 & & & \\
\hline S=34.883 $\mathbf{R}^{2}=31.32 \%$ & & & & & \\
\hline
\end{tabular}

Table 17: ANOVA for Gel Filtration.

\begin{tabular}{|c|c|c|c|c|}
\hline S.NO & Volume in mI & OD & E.A & Total protein \\
\hline Crude extract & $1 \mathrm{ml}$ & 0.991 & 65.7 & 2.98 \\
\hline $\mathrm{NH}_{4} \mathrm{SO}_{4}$ & $1 \mathrm{ml}$ & 1.427 & 94.62 & 1.01 \\
\hline Methanol & $1 \mathrm{ml}$ & 1.676 & 111.1 & 0.89 \\
\hline Isopropanol & $1 \mathrm{ml}$ & 1.76 & 116.7 & 0.31 \\
\hline Gel filtration & $1 \mathrm{ml}$ & 2.11 & 139.91 & 0.33 \\
\hline Ethanol & $1 \mathrm{ml}$ & 1.168 & 77.44 & 0.95 \\
\hline
\end{tabular}

Table 18: Comparison of all purification steps.

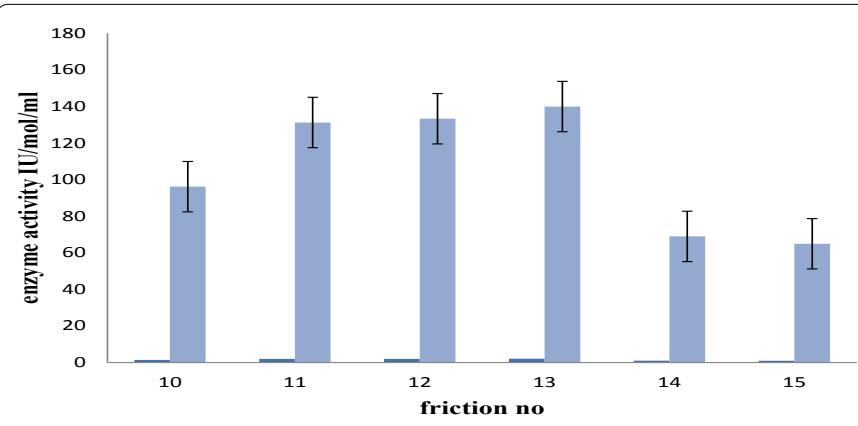

Figure 28: Purification of EPG by using Gel filtration.

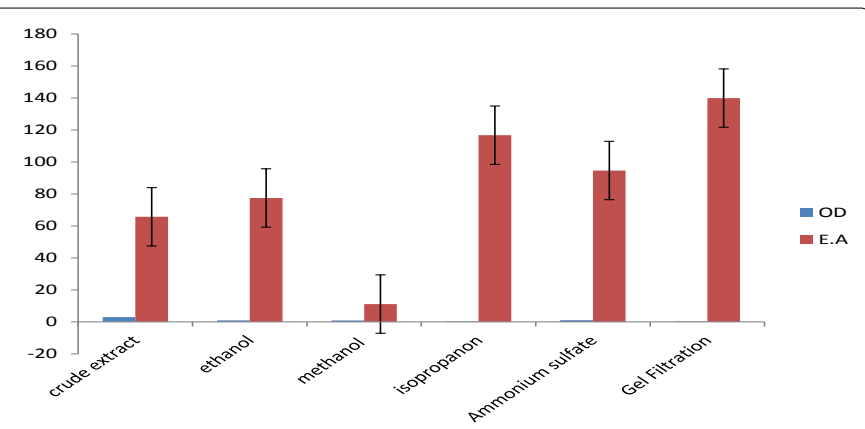

Figure 29: Comparison of different purification steps for EPG production.

\begin{tabular}{|l|c|c|c|c|c|}
\hline Source & DF & SS & MS & F-Value & P-Value \\
\hline Concentration of substrate & 2 & 17447 & 8723.37 & 93.28 & 0.00 \\
\hline OD & 18 & 1683 & 93.52 & & \\
\hline enzyme activity & 20 & 19130 & & & \\
\hline S=9.67073 $\mathrm{R}^{2}=91.20 \%$ & & & & \\
\hline
\end{tabular}

Table 19: ANOVA for Effect of $\mathrm{pH}$ on Enzyme production.

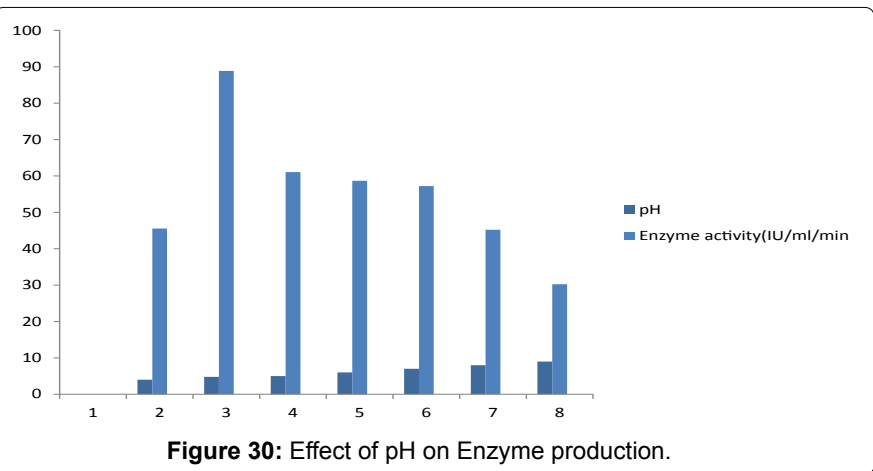


Citation: Munir N, Asad MJ, Haidri SH (2015) Production, Purification and Characterization of Endopolygalacturonase by Bacillus subtillus. Biochem Anal Biochem 4: 181. doi:10.4172/2161-1009.1000181

\begin{tabular}{|l|c|c|c|c|c|}
\hline Source & DF & SS & MS & F-Value & P-Value \\
\hline Concentration of substrate & 2 & 3 & 3.74 & 67 & 0 \\
\hline OD & 15 & 6 & 0.1318 & 10 & \\
\hline enzyme activity & 17 & 9 & 8.73 & & \\
\hline S=5.48673 R $\mathrm{R}^{2}=47.45 \%$ & & & & & \\
\hline
\end{tabular}

Table 20: ANOVA for effect of different substrate concentrations on Enzyme production.

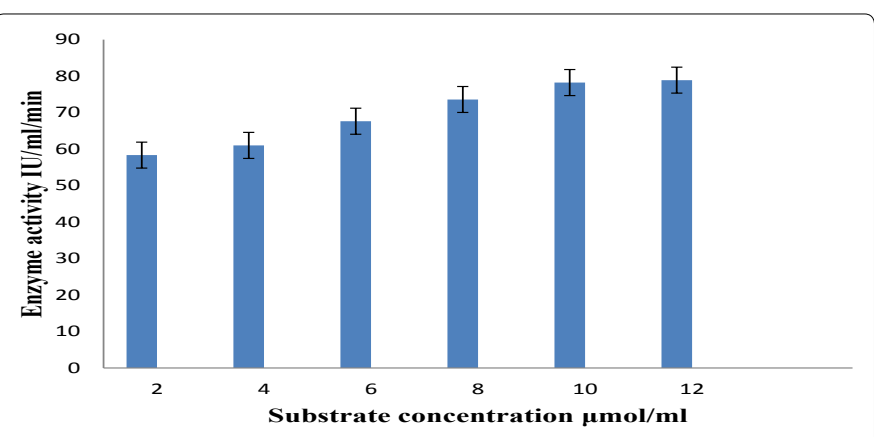

Figure 31: Effect of substrate concentration on Enzyme production.

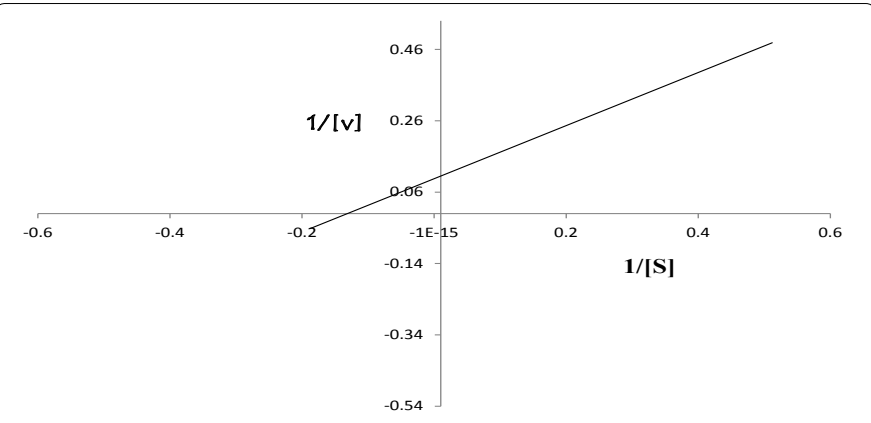

Figure 32: Lineweaver-Burk graph of EPG.

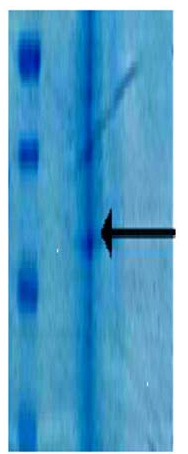

Figure 33: SDS PAGE

in enzyme activity along with increase of substrate concentration. Endopolygalacturonase activity increases when substrate concentration increases from $2 \mathrm{mmol}$ to $4 \mathrm{mmol}$ there was uniform increase in enzyme activity up to $10 \mu \mathrm{mol}$ of substrate and then there was less steep increase from $10 \mathrm{mmol}$ to $12 \mathrm{mmol}$ (Table 20 and Figure 31)

\section{$\mathrm{V}_{\max }$ and $\mathrm{Km}$ for endopolygalacturonase}

Vmax for endopolygalacturonase was and $\mathrm{Km}$ was $1.21 \mathrm{mg} / \mathrm{ml}$ was $2423 \mathrm{~mol} / \mathrm{min} / \mathrm{mg}$ respectively.

\section{Determination of molecular mass of EPG}

Partially purified enzyme after gel filtration was run on SDSPAGE gave a single band of protein viewing its mass at $67 \mathrm{kDa}$. It was recognized as Endopolygalacturonase by enzyme assay (Figure 32,33).

\section{Refernces}

1. Alaña A, Gabilondo A, Hernando F, Moragues MD, Dominguez JB, et al. (1989) Pectin Lyase Production by a Penicillium italicum Strain. Appl Environ Microbiol 55: $1612-1616$.

2. Albersheim $P$ (1966) Pectin lyase from fungi. Meth Enzymol 8: 628-631.

3. Priest FG (1984) Extracellular Enzymes. In: Cole JA, Knowles CJ, Schlessinger D. Asp Microbiol Americ Soc 32: 17-19.

4. Gummadi SN, Panda T (2003) Purification and biochemical properties of microbial Pectinases - A review. Process Biochem 38: 987-996.

5. Dosanjh N, Hoondal GS (1996) Production of constitutive thermostable hyperactive exo-pectinase from Bacillus GK-8. Biotechnol Letters 18: 1435-1438.

6. Maldonado MC, Cáceres S, Galli E, Navarro AR (2002) Regulation of the production of polygalacturonase by Aspergillus niger. Folia Microbiol (Praha) 47: 409-412.

7. Kashyap DR, Vohra PK, Chopra S, Tewari R (2001) Applications of pectinases in the commercial sector: a review. Bioresour Technol 77: 215-227.

8. Ahlawat S, Mandhan RP, Dhiman SS, Kumar R, Sharma J (2008) Potential application of alkaline pectinase from Bacillus subtilis $S S$ in pulp and paper industry. Appl Biochem Biotechnol 149: 287-293.

9. Jayani RS, Shukla SK, Gupta R (2010) Screening of Bacterial Strains for Polygalacturonase Activity: Its Production by Bacillus sphaericus (MTCC 7542). Enzyme Res 2010: 306785.

10. Sakai T, Sakamoto T, Hallaert J, Vandamme EJ (1993) Pectin, pectinase and protopectinase: production, properties, and applications. Adv Appl Microbiol 39: 213-294.

11. Davé BA, Vaughn RH (1971) Purification and properties of an polygalacturonic acid trans-eliminase produced by Bacillus pumilus. J Bacteriol 108: 166-174.

12. Brühlmann $F$ (1995) Purification and characterization of an extracellular pectate lyase from an Amycolata sp. Appl Environ Microbiol 61: 3580-3585.

13. Pilnik WA, Voragen GJ (1993) Pectic enzymes in fruit juice and vegetable juice manufacture. In: Reeds G (ed), Food and Science Technology. Enz Food Processing New York, 42: 363-399.

14. Kilara A (1982) Enzymes and their uses in the processed apple industry: A Review Proc Biochem 23: 35-41.

15. Alkorta I, Garbisu C, Llama MJ, Serra JL (1998) Industrial applications of pectic enzymes: Review Proc Biochem 33: 21-28.

16. Yamaski M, Yasui T, Arima K (1964) Pectic enzymes in the clarification of apple juices. Part I. Study on the clarification reaction in a simplified model. Agric Biol Chem 28: 779-787.

17. Robertson GL (1977) Pectic enzymes and wine making. Food Technol New Zealand 12: 34-35.

18. Pilnik W (1982) Enzyme in the beverage industry. In: Dupuy $P$ (ed.), Use of Enzymes in Food Technology. Tech Doc Lavosier Paris 32: 425-450.

19. Beldman G, Rombouts FM, Voragen AGJ, Pilnik W (1984) Application of cellulase and pectinase from fungal origin for the liquefaction and sachharification of biomass. Enz Microbiol Technol 6: 503-507.

20. Prathyusha K, Suneetha V (2011) Bacterial Pectinases and their Potent Biotechnological Application in Fruit Processing/Juice Production Industry: Review J Phytol 3: 16-19.

21. Bensadoun A, Weinstein D (1976) Assay of proteins in the presence of interfering materials. Anal Biochem 70: 241-250.

22. Tamburini E, León AG, Perito B, Mastromei G (2003) Characterization of bacterial pectinolytic strains involved in the water retting process. Environ Microbiol 5: 730-736. 
Citation: Munir N, Asad MJ, Haidri SH (2015) Production, Purification and Characterization of Endopolygalacturonase by Bacillus subtillus. Biochem Anal Biochem 4: 181. doi:10.4172/2161-1009.1000181

23. Miller JNB (1986) An introduction to pectins: Structure and properties. In: Fishman ML, Jem JJ (eds.), Chemistry and Functions of Pectins, ACS Symposium Series 310. Amer Chem Socei, Washi. DC 31: 299-302.
24. Andrade MVVD, Delatorre AB, Ladeira SA, Martins MLL (2011) Production and partial characterization of alkaline polygalacturonase secreted by thermophilic HBacillus sp. SMIA-2 under submerged culture using pectin and corn steep liquor. Appl Biochem Biotechnol 31: 204-208. 